\title{
Determination of Some Engineering Properties of Groundnut Pod (Gg-20 Variety)
}

\author{
Saumya Shukla*, Ajay Makwana and R.A. Gupta
}

Department of Farm Machinery and Power Engineering, Junagadh Agricultural University, Junagadh-362001, Gujarat, India

*Corresponding author

\begin{tabular}{|c|c|}
\hline & A B S T R A C T \\
\hline $\begin{array}{l}\text { K e y w o r d s } \\
\text { Groundnut Pod, } \\
\text { Engineering } \\
\text { properties }\end{array}$ & \multirow{3}{*}{$\begin{array}{l}\text { For the design of equipment for harvesting, grading, cleaning, sorting, separation } \\
\text { and packaging, the engineering properties of groundnut is essential. The aim of } \\
\text { this investigation to study the main physical and mechanical properties of } \\
\text { groundnut pod (GG- } 20 \text { variety). Some of the engineering properties, such as } \\
\text { weight, size, shape, angle of repose, bulk density, coefficient of friction and } \\
\text { terminal velocity were determined. The properties of selected groundnut variety } \\
\text { i.e. GG- } 20 \text { pod observed in terms of equivalent diameter, sphericity, bulk density, } \\
\text { angle of repose, coefficient of friction and terminal velocity were } 16.66 \mathrm{~mm}, 0.55 \text {, } \\
0.286 \mathrm{~g} / \mathrm{cc}, 24^{\circ}, 0.035 \text { and } 10.27 \mathrm{~m} / \mathrm{s} \text {, respectively. }\end{array}$} \\
\hline Article Info & \\
\hline $\begin{array}{l}\text { Accepted: } \\
\text { 22 January } 2019 \\
\text { Available Online: } \\
\text { 10 February } 2019\end{array}$ & \\
\hline
\end{tabular}

\section{Introduction}

Groundnut (Archis hypogaea $\mathrm{L}$ ) or peanut is one of the most important cash crops of our country and it plays a major role in bridging the vegetable oil deficit in the country. Groundnuts in India are available throughout the year due to a two-crop cycle harvested in March and October. In India the six major groundnut-growing states are Andhra Pradesh, Gujarat, Karnataka, Maharashtra, Rajasthan and Tamil Nadu account for about $90 \%$ of the total groundnut area of the country. Andhra Pradesh and Gujarat contribute more than $55 \%$ of the total area and production of groundnut. Among the major groundnut growing states, Gujarat is the most important one accounting for $36 \%$ of the total area.

Groundnut has several uses as whole seeds or is processed to make groundnut butter, oil, and other products (Putnam et al., 2013). Groundnut is one of the most important oilseed plants in the world. Its seeds contain $40-50 \%$ fat, $20-50 \%$ protein and $10-20 \%$ carbohydrate depending on the variety (Okello et al., 2010).

The physical and mechanical properties of groundnut pods play an important role in problems associated with design or 
development of sieve unit, a specific machine, handling, cleaning and storage (Mohsenin, 1980; Aviara et al., 1999). Recently, some studies have been done on some properties of groundnut kernels and pods (Firouzi et al., 2009, Jean-Baptiste, et al., 2012, Fashina et al., 2014 and Kazeem et al., (2015).

\section{Materials and Methods}

\section{Sampling}

Engineering properties of groundnut pods of semi-spreading variety (GG-20) were measured and evaluated at Dept. of Processing and Food Engg., Junagadh Agril. University, India. Moisture content was immediately measured on arrival. The experiments were conducted at the moisture content of $8.2 \%$ dry basis (d.b).

\section{Determination of Size}

The size of groundnut pods was determined in terms of length (L), width (W) and thickness (T). Fifty pods of GG-20 variety were taken and dimensions $\mathrm{L}, \mathrm{W}$ and $\mathrm{T}$ (Figure 1) were measured at three major axes with the help of Digital Vernier Caliper (Figure 2) having least count of $0.1 \mathrm{~mm}$. the longest dimension in the longitudinal direction is considered as length, while the dorsovental dimension was measured as width and the third axis lateral dimension was measured as the thickness of the seed.

Size of each pod in terms of equivalent diameter (De) was determined by using following formula: (Mohsenin, 1986)

$\mathrm{De}=\sqrt[s]{(\mathrm{L} \times \mathrm{W} \times \mathrm{T})}$

\section{Sphericity}

The sphericity of seeds was calculated by using the following relationship (Mohsenin, 1986):
Sphericity $(\mathrm{S})=\frac{\sqrt[\mathbb{8}]{(\mathrm{L} \times \mathrm{W} \times \mathrm{T})}}{\mathrm{L}} \ldots$

Where,

$\mathrm{De}=$ Equivalent diameter $(\mathrm{mm})$

$\mathrm{L}=$ Largest intercept $(\mathrm{mm})$ i.e. maximum intercept

$\mathrm{W}=$ Largest intercept perpendicular to $\mathrm{L}$ $(\mathrm{mm})$ i.e. intermediate intercept

$\mathrm{T}=$ Largest intercept perpendicular to $\mathrm{L}$ and $\mathrm{W}(\mathrm{mm})$ i.e. minimum intercept

\section{Bulk density}

Bulk density of the groundnut pods is defined as the ratio of weight of pods to the volume of the same pods. Bulk density of pods was required for designing of separating unit. The seeds were filled in a 1000 cc capacity cylinder without undue pressure and its weight was measured on an electronic balance having least count of $0.1 \mathrm{~g}$. The bulk density was calculated as weight of material per unit volume, g/cc. Bulk density of pods was determined by using following equation

Bulk density $(\mathrm{g} / \mathrm{cc})=\frac{\text { Mass (W2-W1) }}{\text { Volume of container }(\mathrm{V})} \ldots$

Where,

$\mathrm{W} 1$ = empty weight of container, $\mathrm{g}$

W2 = weight of container filled with pods, $g$ $\mathrm{V}=$ volume of container, $\mathrm{cm}^{3}$

\section{Angle of repose}

The angle of repose was determined by the method explained by Waziri and Mittal (1983). The apparatus used for measurement of angle of repose of pods is shown in Figure 3. Three replicated trials were conducted.

The pods were filled into the box having circular platform, surrounded by a metal funnel leading to discharge hole. The pods were allowed to escape from the box leaving a free standing cone of pods on the platform. 
Table.1 Engineering properties of groundnut pod

\begin{tabular}{|c|c|c|c|c|c|}
\hline $\begin{array}{l}\text { Sr. } \\
\text { No. }\end{array}$ & \multicolumn{2}{|c|}{ Engineering property } & $\begin{array}{c}\text { Minimum } \\
\text { Value }\end{array}$ & $\begin{array}{l}\text { Maximum } \\
\text { Value }\end{array}$ & $\begin{array}{c}\text { Average } \\
\text { Value }\end{array}$ \\
\hline \multirow[t]{4}{*}{1} & \multirow[t]{4}{*}{ Size } & Length, mm & 16.39 & 44.51 & 27.86 \\
\hline & & Width, mm & 10.60 & 16.04 & 13.78 \\
\hline & & Thickness, mm & 9.41 & 14.29 & 12.06 \\
\hline & & $\begin{array}{c}\text { Equivalent } \\
\text { diameter, mm }\end{array}$ & 12.16 & 20.32 & 16.66 \\
\hline 2 & \multicolumn{2}{|r|}{ Sphericity } & 0.46 & 0.68 & 0.55 \\
\hline 3 & \multicolumn{2}{|c|}{ Single pod weight, $g$} & 1.54 & 2.37 & 1.86 \\
\hline 4 & \multicolumn{2}{|c|}{ Bulk density, g/cc } & 0.285 & 0.289 & 0.286 \\
\hline 5 & \multicolumn{2}{|c|}{ Angle of repose, ${ }^{\circ}$} & 21.98 & 27.8 & 24 \\
\hline 6 & \multicolumn{2}{|c|}{ Coefficient of friction } & 0.03 & 0.038 & 0.035 \\
\hline 7 & \multirow{2}{*}{\multicolumn{2}{|c|}{ Shape }} & \multicolumn{3}{|c|}{ Oblong } \\
\hline 8 & & Terminal velocity, $\mathrm{m} / \mathrm{s}$ & 9.40 & 11.20 & 10.27 \\
\hline
\end{tabular}

Fig.1 Axis and three major perpendicular dimensions of groundnut pods

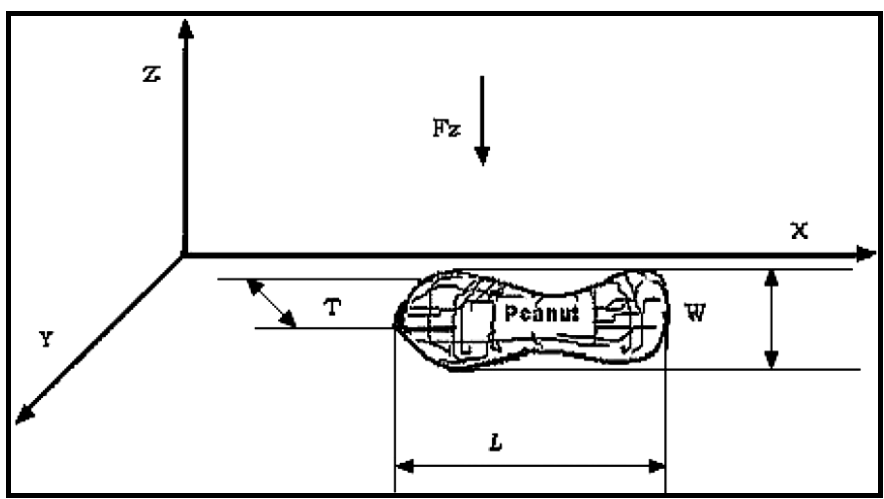

Fig.2 Determination of size of groundnut pod

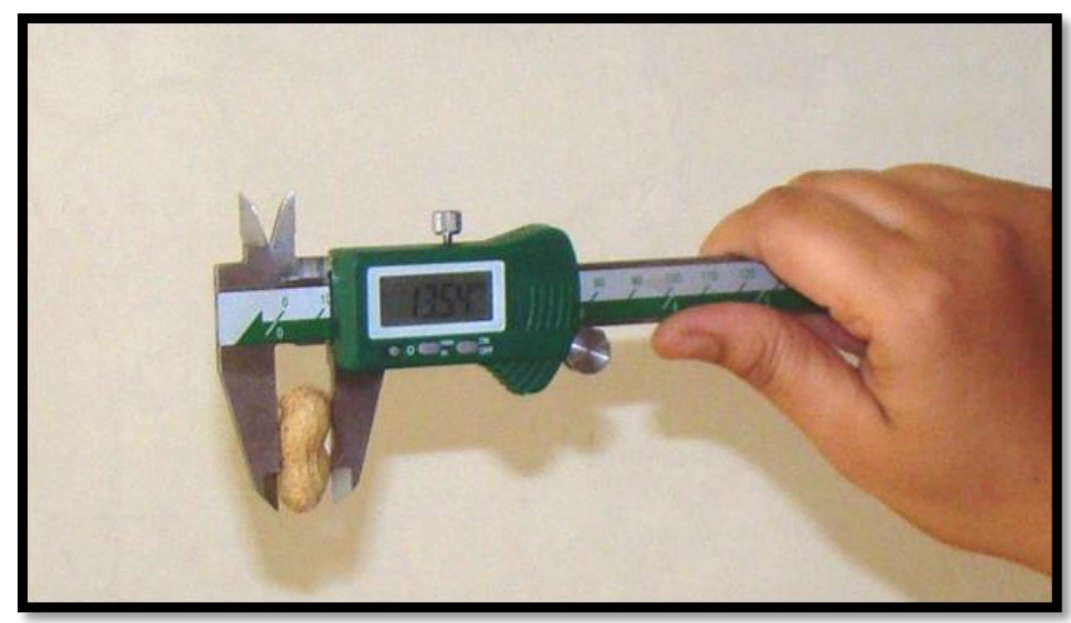


Fig.3 Apparatus for measurement of static angle of repose for pods

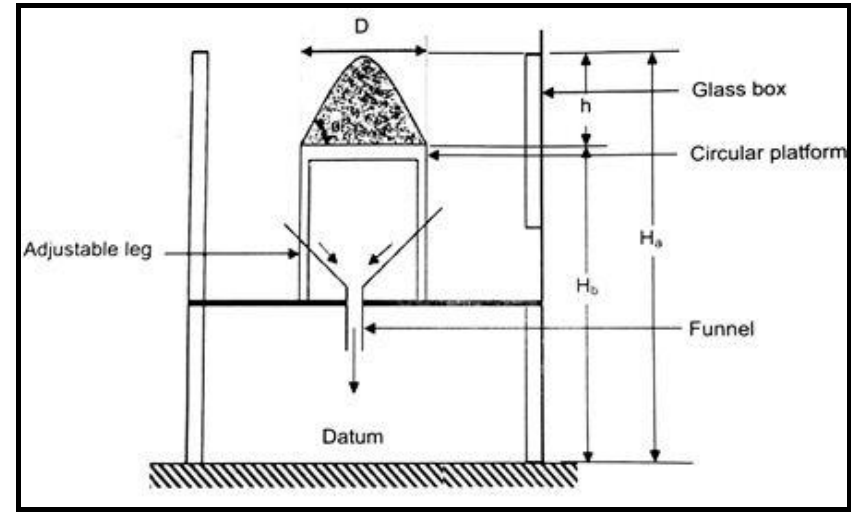

Fig.4 Tilting table apparatus for measurement of coefficient of friction

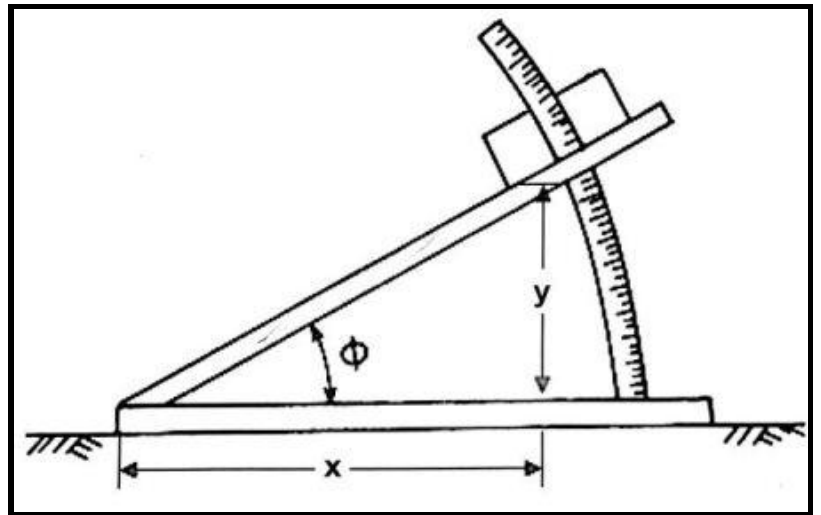

Fig.5 Anemometer

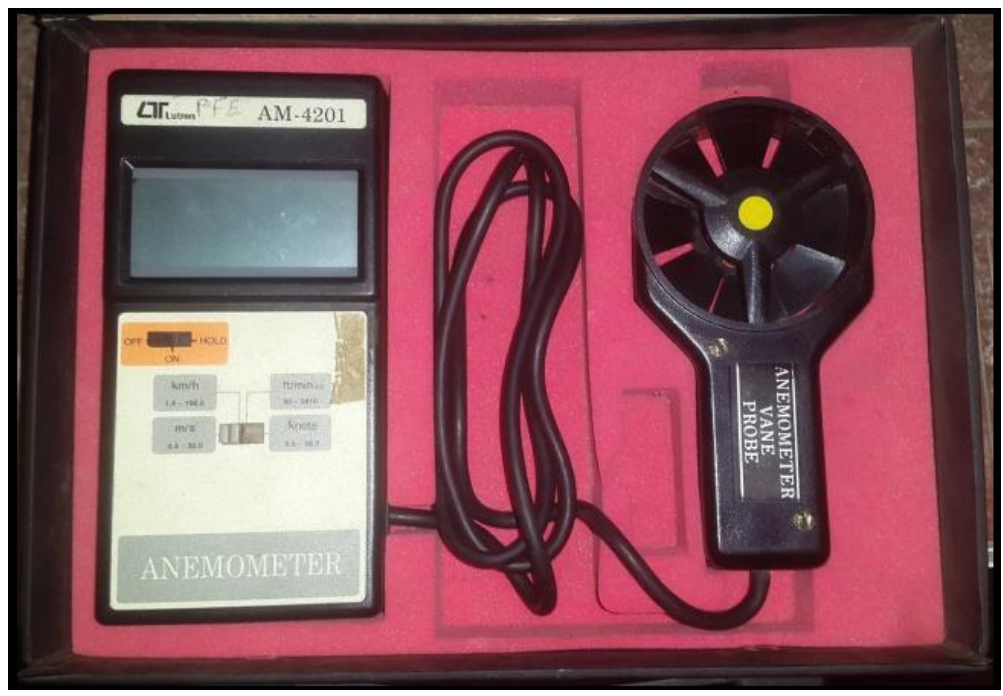


Fig.6 Setup for measurement of terminal velocity

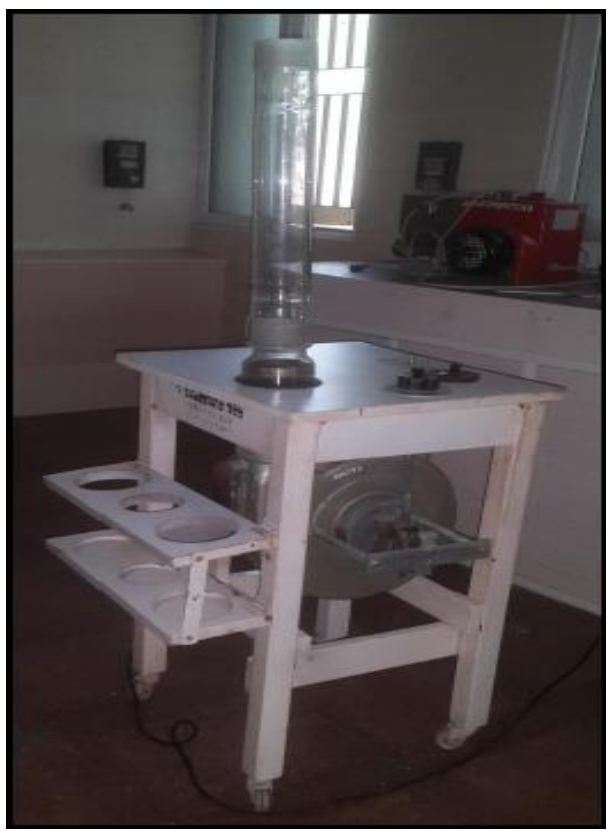

Then measured the height (h) of the cone and diameter (D) of the platform with the help of traveling microscope and calculated the angle of repose by following formula,

$$
\theta=\tan ^{-1} \frac{2 \mathrm{~h}}{\mathrm{D}}
$$

Where,

$\theta=$ angle of repose (degree)

$\mathrm{h}=\mathrm{H}_{\mathrm{a}}-\mathrm{H}_{\mathrm{b}}$

$\mathrm{D}=$ Diameter of circular platform

\section{Coefficient of friction}

The method of inclined plane apparatus described by Dutta et al., (1988) was used to determine the coefficient of static friction. The table gently raised and the angle of inclination to the horizontal at which the sample starts to slide was read off from the protractor attached to the apparatus (Figure 4). The tangent of the angle was reported as the coefficient of static friction.

The following equation was used to calculate the coefficient of friction and angle of internal friction for the groundnut pods. $\mu=\tan \emptyset=(y / x)$

$\varnothing=\tan ^{-1}(\mathrm{y} / \mathrm{x})$

Where,

$\mu$ is the coefficient of friction

$\varnothing$ is the angle of internal friction.

\section{Aerodynamic properties (Terminal velocity)}

Terminal velocity is the air velocity at which a particle remains in suspended state in a vertical pipe. Five random samples of pods were selected and their terminal velocity was measured using a terminal velocity measurement apparatus (Figure 5). Anemometer vane probe was used to measure the terminal velocity. Anemometer and the setup for measurement of terminal velocity of the seeds are shown in Figure 5 and 6.

\section{Results and Discussion}

The average values for the length, width, thickness, dimensions, equivalent diameter, sphericity and surface area of groundnut measured at moisture contents $8.2 \%$ (d.b.) are given in Table 1. 
The size of the groundnut pods, specified by length, width and thickness were used in determining the size of openings of sieves. The average length, width and thickness of pods were found to be $27.86 \mathrm{~mm}, 13.78 \mathrm{~mm}$ and $12.06 \mathrm{~mm}$, respectively (Table 1 ). The average equivalent diameter was found to be $16.66 \mathrm{~mm}$. Sphericity was determined to define the shape of groundnut pods. The average sphericity was obtained as 0.55 (Table 1). On the basis of sphericity, the shape of groundnut pods comes under the category of oblong. The ability of any grains or fruits to either roll or slide depends on the sphericity. The average bulk density groundnut pod was obtained as $0.286 \mathrm{~g} / \mathrm{cc}$ (Table 1). Bulk density was required to design the capacity and dimensions of sieve box. The average value of angle of repose of groundnut pod was observed as $24^{\circ}$. The average coefficient of friction of pods was found as 0.035. It was observed that the smoother the structural surface the lower the coefficient of friction of agricultural products. Mean terminal velocity of pods of GG-20 variety was found as $10.27 \mathrm{~m} / \mathrm{s}$.

\section{References}

Aviara, N.A., M.I. Gwandzung and M.A.M. Hague, 1999. Physical properties of guna seeds. Jr. of Agri. Engg. Res., 73:105111.

Dutta, S. K., Nema, V. K. and Bhardwaj, R. K. (1988). Physical properties of grains. Journal of Agricultural Engineering Research. 39: 259-268.

Fashina, A. B., Saleh, A. and Akande, F. B. 2014.Some engineering properties of three selected groundnut (Arachis hypogaea L.) varieties cultivated in Nigeria. Agric Eng Int: CIGR Journal, 16(4): 268-277.

Firouzi, S., Vishgaei, M. N. S. and Kaviani. B. 2009. Some physical properties of groundnut (Arachis hypogaea L.) Kernel $\mathrm{cv}$. NC2 as a function of moisture content. American-Eurasian Journal of Agriculture and Environmental Science, 6(6), 675-679.

Jean-Baptiste, N. T., Souina, G., Nicolas, N. Y. N., Richard, M. and Arlette, Z. Z. 2012. Genetic variability and heritability estimates of some properties of groundnut (Arachis hypogaea L.) kernels. International (Journal of Biosciences IJB), 2(1): 25-35.

Kazeem, O. O., Kazeem, A. A., Tajudeen, S. A. O. and Taiwo, O. I. 2015. Estimation of engineering parameters for the development of a groundnut decorticator. International Journal of Novel Research in Engineering and Applied Sciences, 2(1): $1-25$.

Mohsenin, N.N., 1980. Physical properties of plant and animal materials. Gordon and Breach Science Publishers, New York.

Okello, D. K., Biruma, M. and Deom, C. M. 2010. Overview of groundnuts research in Uganda: Past, present and future. African Journal of Biotechnology, 9(39): 64486459.

Putnam, D. H., Oplinger, E. S., Teynor, T. M., Oelke, E. A., Kelling, K. A. and Doll, J. D. 2013. Alternative Field Crops Manual. Peanut.

Waziri, A. N. and Mittal, J. P. (1983). Design related physical properties of selected agricultural products. AMA, 14: 59-62.

\section{How to cite this article:}

Saumya Shukla, Ajay Makwana and Gupta, R.A. 2019. Determination of Some Engineering Properties of Groundnut Pod (Gg-20 Variety). Int.J.Curr.Microbiol.App.Sci. 8(02): 3025-3030. doi: https://doi.org/10.20546/ijcmas.2019.802.354 